Supporting Information

\title{
Washing- and Separation-Free Electrochemical Detection of Porphyromonas gingivalis in Saliva for Initial Diagnosis of Periodontitis
}

Seonhwa Park, ${ }^{\S, \dagger}$ Kiryeon Park,,$^{\S, \dagger}$ Hee Sam Na, ${ }^{\S, \dagger}$ Jin Chung, ${ }^{*}, \dot{\dagger}$ and Haesik Yang, ${ }^{*}$

${ }^{\dagger}$ Department of Chemistry and Chemistry Institute for Functional Materials, Pusan National University, Busan 46241, Korea

Department of Oral Microbiology, School of Dentistry, Pusan National University, Gyeongsangnam-do 50612, Korea 


\section{Table of Content}

Table S1. Bacteria strains used in this study.

Figure S1. Histograms of the charge values measured at $100 \mathrm{~s}$ in the chronocoulograms obtained at CNT- and BSA-modified ITO electrodes in Tris buffer ( $\mathrm{pH}$ 7.5) containing (i) $0.1 \mathrm{mM}$ GPR-AP, $2.0 \mathrm{mM}$ TCEP, and $50 \mathrm{mM}$ Gly-Gly and (ii) $0.1 \mathrm{mM} \mathrm{AP,} 2.0 \mathrm{mM}$ TCEP, and $50 \mathrm{mM}$ Gly-Gly.

Figure S2. Chronocoulograms obtained (at $0.25 \mathrm{~V}$ ) at CNT- and BSA-modified ITO electrodes after an incubation period of $15 \mathrm{~min}$ at $55^{\circ} \mathrm{C}$ in Tris buffer $(\mathrm{pH} 7.5)$ containing (i) $0.1 \mathrm{mM}$ GPR-AP and $2.0 \mathrm{mM}$ TCEP, (ii) $0.1 \mathrm{mM}$ GPR-AP, $2.0 \mathrm{mM}$ TCEP, and $10^{7}$ CFU/mL P. ginivalis, (iii) $0.1 \mathrm{mM}$ GPR-AP, $2.0 \mathrm{mM}$ TCEP, and $5.0 \mathrm{mM}$ cysteine, and (ii) $0.1 \mathrm{mM}$ GPR-AP, $2.0 \mathrm{mM}$ TCEP, $10^{7} \mathrm{CFU} / \mathrm{mL}$ P. ginivalis, and $5.0 \mathrm{mM}$ cysteine.

Figure S3. (a) Cyclic voltammograms (at a scan rate of $20 \mathrm{mV} / \mathrm{s}$ ) and (b) chronocoulograms (at $0.25 \mathrm{~V}$ ) obtained at CNT- and BSA-modified electrodes after an incubation period $15 \mathrm{~min}$ at $55^{\circ} \mathrm{C}$ in Tris buffer ( $\mathrm{pH}$ 7.5) containing (i) $0.1 \mathrm{mM}$ benzonyl-R-AP, $2.0 \mathrm{mM}$ TCEP, and $50 \mathrm{mM}$ Gly-Gly and (ii) $0.1 \mathrm{mM}$ benzonyl-R-AP, $2.0 \mathrm{mM}$ TCEP, $50 \mathrm{mM}$ Gly-Gly, and $10^{7} \mathrm{CFU} / \mathrm{mL} P$. gingivalis.

Figure S4. (a) Comparison of the absorbance values measured at $380 \mathrm{~nm}$ in UV-Vis spectrums obtained after an incubation period of $30 \mathrm{~min}$ at $37{ }^{\circ} \mathrm{C}$ in a mixed solution of Tris buffer ( $\mathrm{pH} 7.5$ ) containing $25 \mu \mathrm{g} / \mathrm{mL}$ BANA, $50 \mathrm{mM}$ Gly-Gly, $5.0 \mathrm{mM}$ cysteine, and artificial saliva containing (i) no bacteria, $10^{7} \mathrm{CFU} / \mathrm{mL}$ (ii) $P$. gingivalis, (iii) $P$. gingivalis MT10, and (iv) $P$. gingivalis MT10w. Comparison of the absorbance values in panel a. Artificial saliva contained $10^{7} \mathrm{CFU} / \mathrm{mL}$ bacteria [1: no bacteria, 2: P. gingivalis, 3: $P$. gingivalis MT10, 4: P. gingivalis MT10w, 5: T. denticola, 6: T. forsythia, 7: S. mitis, 8: S. salivarius, 9: $P$. intermedia, 10: A actinomycetemcomitans, 11: P. endodontalis, 12: F. nucleatum, 13: E. coli, 14: E. faecalis, 15: N. mucosa, and 16: S. mutans].

Figure S5. Chronocoulograms obtained (at $0.25 \mathrm{~V}$ ) using the schematic diagram of Figure 1 in artificial saliva containing various concentrations of $P$. gingivalis at a CNTand BSA-modified ITO electrodes before an incubation period of $15 \mathrm{~min}$ at $55^{\circ} \mathrm{C}$ in Tris buffer (pH 7.5) containing 0.1 mM GPR-AP, $2.0 \mathrm{mM}$ TCEP, and $50 \mathrm{mM}$ Gly-Gly.

Table S2. Comparison of the developed method with other methods.

Figure S6. Chronocoulograms obtained (at $0.25 \mathrm{~V}$ ) using the schematic diagram of Figure 1 in human saliva at CNT- and BSA-modified ITO electrodes before (i, iii) and after (ii, iv) an incubation period of $15 \mathrm{~min}$ at $55^{\circ} \mathrm{C}$ in (i, ii) a mixed solution of $300 \mu \mathrm{L}$ of human saliva and $200 \mu \mathrm{L}$ of Tris buffer ( $\mathrm{pH} 7.5$ ) containing $0.1 \mathrm{mM}$ GPR-AP, $2.0 \mathrm{mM}$ TCEP, and $50 \mathrm{mM}$ Gly-Gly, and (iii, iv) a mixed solution of $300 \mu \mathrm{L}$ of human saliva spiked with $10^{7} \mathrm{CFU} / \mathrm{mL} P$. gingivalis and $200 \mu \mathrm{L}$ of Tris buffer $(\mathrm{pH} 7.5)$ containing 0.1 mM GPR-AP, 2.0 mM TCEP, and $50 \mathrm{mM}$ Gly-Gly. 
Table S1. Bacteria strains used in this study.

\begin{tabular}{cc}
\hline Species & Strain \\
\hline Porphyromonas gingivalis & strain 381 \\
Porphyromonas gingivalis MT10 & strain 381 \\
Porphyromonas gingivalis & strain 381 \\
MT10w & ATCC 35406 \\
Porphyromonas endodontalis & ATCC 33384 \\
Aggregatibacter & ATCC 23726 \\
actinomycetemcomitans & DH5a \\
Fusobacterium nucleatum & ATCC29212 \\
Escherichia coli & ATCC 19696 \\
Enterococcus faecalis & ATCC 25611 \\
Neisseria mucosa & ATCC 34308 \\
Prevotella intermedia & ATCC 10827 \\
Treponema denticola & ATCC 49456 \\
Tannerella forsythia & ATCC 25175 \\
Streptococcus mitis & ATCC 7073 \\
Streptococcus mutans &
\end{tabular}




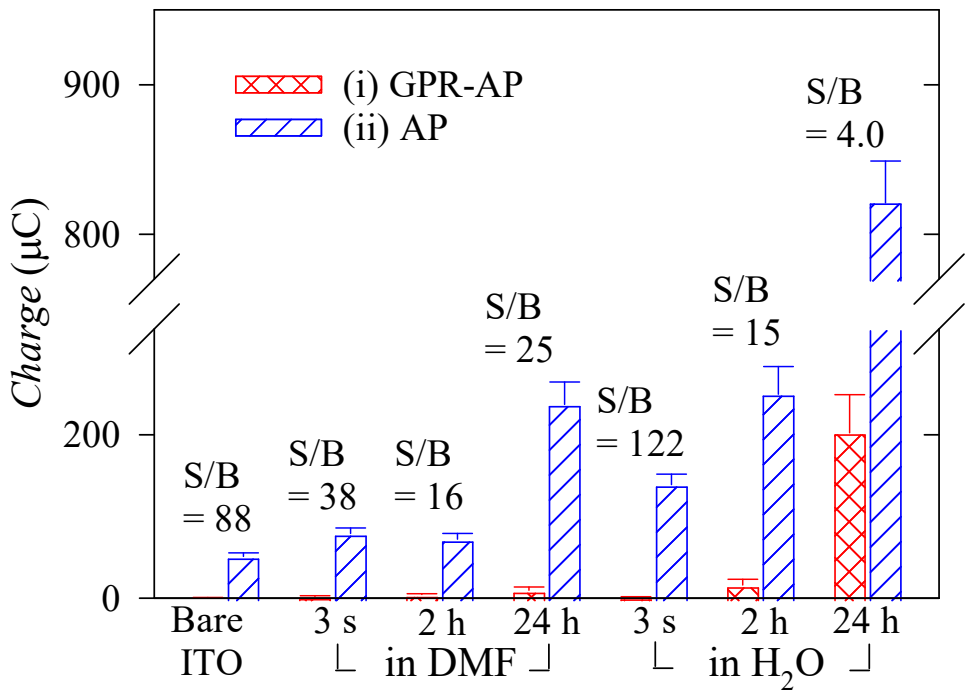

Figure S1. Histograms of the charge values measured at $100 \mathrm{~s}$ in the chronocoulograms obtained at CNT- and BSA-modified ITO electrodes in Tris buffer ( $\mathrm{pH}$ 7.5) containing (i) $0.1 \mathrm{mM}$ GPR-AP, $2.0 \mathrm{mM}$ TCEP, and $50 \mathrm{mM}$ Gly-Gly and (ii) $0.1 \mathrm{mM} \mathrm{AP,} 2.0 \mathrm{mM}$ TCEP, and $50 \mathrm{mM}$ Gly-Gly. 


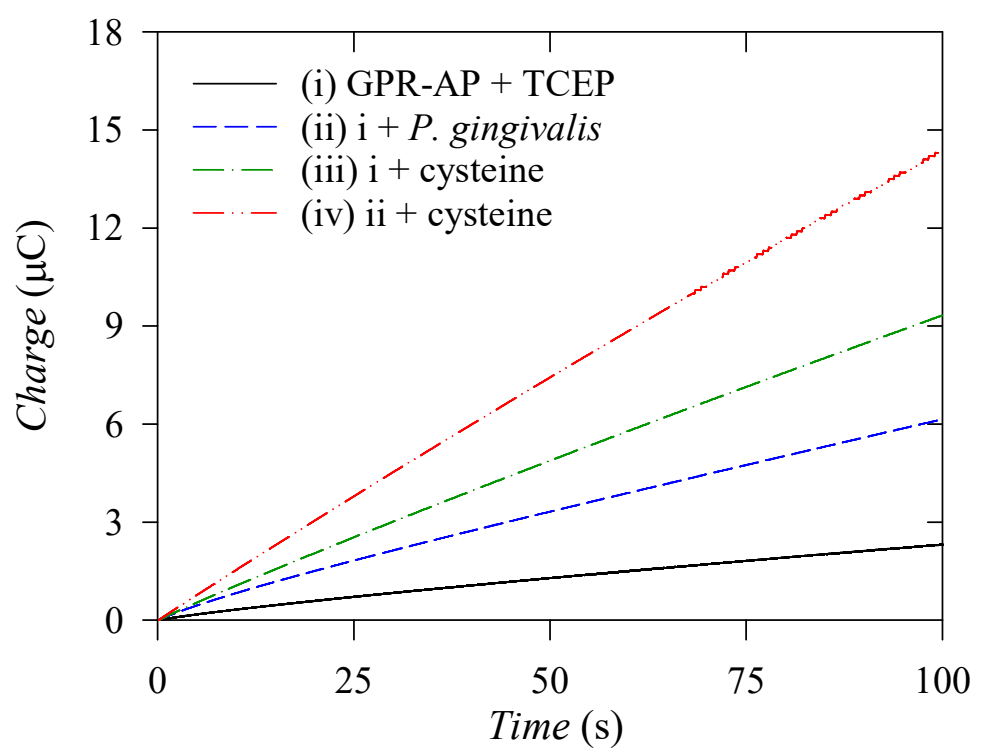

Figure S2. Chronocoulograms obtained (at $0.25 \mathrm{~V}$ ) at CNT- and BSA-modified ITO electrodes after an incubation period of $15 \mathrm{~min}$ at $55^{\circ} \mathrm{C}$ in Tris buffer $(\mathrm{pH} 7.5)$ containing (i) $0.1 \mathrm{mM}$ GPR-AP and $2.0 \mathrm{mM}$ TCEP, (ii) $0.1 \mathrm{mM}$ GPR-AP, $2.0 \mathrm{mM}$ TCEP, and $10^{7}$ CFU/mL P. ginivalis, (iii) $0.1 \mathrm{mM}$ GPR-AP, $2.0 \mathrm{mM}$ TCEP, and $5.0 \mathrm{mM}$ cysteine, and (ii) $0.1 \mathrm{mM}$ GPR-AP, $2.0 \mathrm{mM}$ TCEP, $10^{7} \mathrm{CFU} / \mathrm{mL}$ P ginivalis, and $5.0 \mathrm{mM}$ cysteine. 

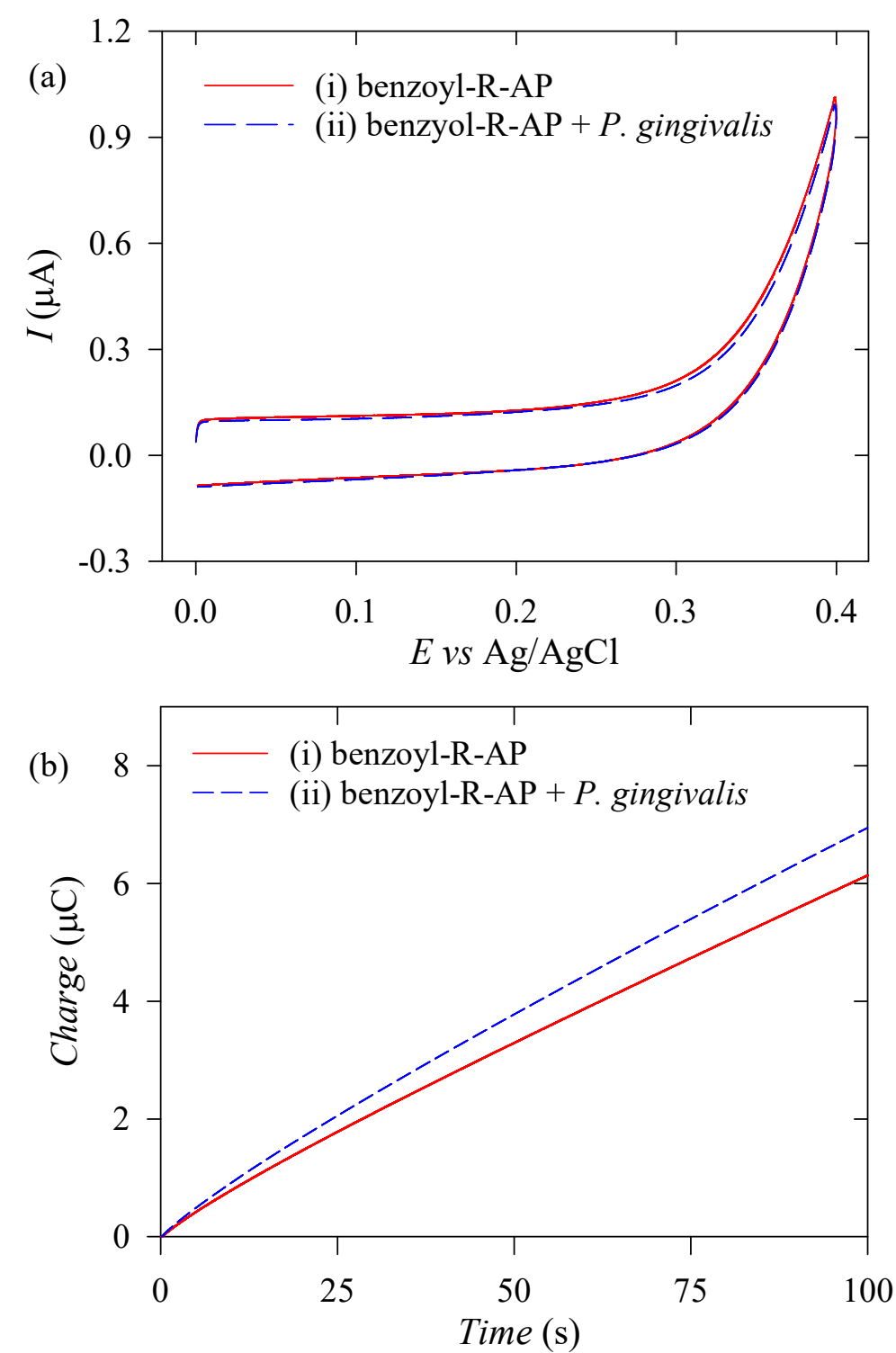

Figure S3. (a) Cyclic voltammograms (at a scan rate of $20 \mathrm{mV} / \mathrm{s}$ ) and (b) chronocoulograms (at $0.25 \mathrm{~V}$ ) obtained at CNT- and BSA-modified electrodes after an incubation period $15 \mathrm{~min}$ at $55^{\circ} \mathrm{C}$ in Tris buffer ( $\mathrm{pH}$ 7.5) containing (i) $0.1 \mathrm{mM}$ benzonyl-R-AP, $2.0 \mathrm{mM}$ TCEP, and $50 \mathrm{mM}$ Gly-Gly and (ii) $0.1 \mathrm{mM}$ benzonyl-R-AP, $2.0 \mathrm{mM}$ TCEP, $50 \mathrm{mM}$ Gly-Gly, and $10^{7} \mathrm{CFU} / \mathrm{mL} P$. gingivalis. 

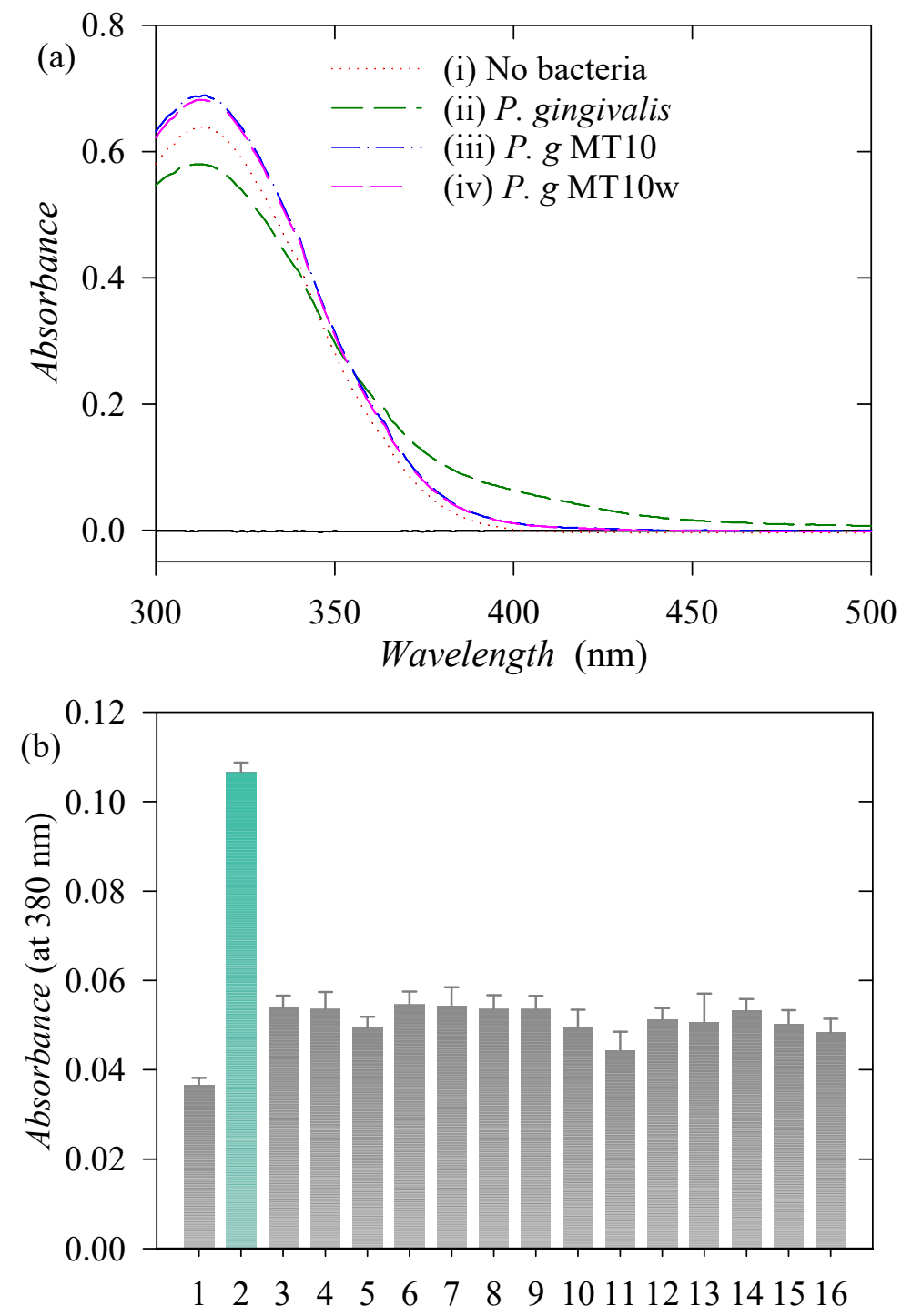

Figure S4. (a) Comparison of the absorbance values measured at $380 \mathrm{~nm}$ in UV-Vis spectrums obtained after an incubation period of $30 \mathrm{~min}$ at $37^{\circ} \mathrm{C}$ in a mixed solution of Tris buffer ( $\mathrm{pH} 7.5$ ) containing $25 \mu \mathrm{g} / \mathrm{mL}$ BANA, $50 \mathrm{mM}$ Gly-Gly, $5.0 \mathrm{mM}$ cysteine, and artificial saliva containing (i) no bacteria, $10^{7} \mathrm{CFU} / \mathrm{mL}$ (ii) $P$. gingivalis, (iii) $P$. gingivalis MT10, and (iv) $P$. gingivalis MT10w. (b) Comparison of the absorbance values in panel a. Artificial saliva contained $10^{7} \mathrm{CFU} / \mathrm{mL}$ bacteria [1: no bacteria, $2: P$. gingivalis, $3: P$. gingivalis MT10, 4: P. gingivalis MT10w, 5: T. denticola, 6: T. forsythia, 7: S. mitis, 8: S. salivarius, 9: $P$. intermedia, 10: A actinomycetemcomitans, 11: P. endodontalis, 12: F. nucleatum, 13: E. coli, 14: E. faecalis, 15: N. mucosa, and 16: S. mutans]. 


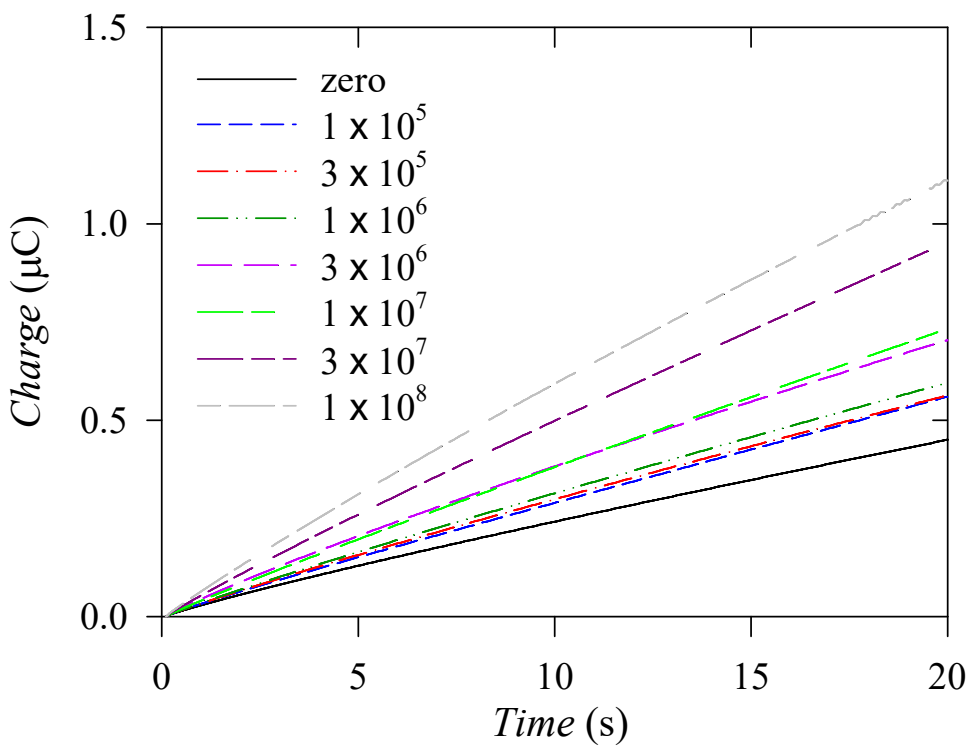

Figure S5. Chronocoulograms obtained (at $0.25 \mathrm{~V}$ ) using the schematic diagram of Figure 1 in artificial saliva containing various concentrations of $P$. gingivalis at a CNTand BSA-modified ITO electrodes before an incubation period of $15 \mathrm{~min}$ at $55^{\circ} \mathrm{C}$ in Tris buffer (pH 7.5) containing 0.1 mM GPR-AP, $2.0 \mathrm{mM}$ TCEP, and $50 \mathrm{mM}$ Gly-Gly. 
Table S2. Comparison of the developed method with other methods.

\begin{tabular}{|c|c|c|c|c|c|}
\hline Detection technique & $\begin{array}{l}\text { Signaling } \\
\text { method }\end{array}$ & Sample & $\begin{array}{l}\text { Detection } \\
\text { time }\end{array}$ & Detection limit & Ref. \\
\hline BANA test & Colorimetry & Saliva & $5-15 \min$ & $\begin{array}{l}\text { Distinguishing negative, } \\
\text { weak positive, and positive }\end{array}$ & $8-11$ \\
\hline Real-time PCR & Fluorescence & Saliva & $\sim 30 \mathrm{~min}$ & $\begin{array}{l}\text { Distinguishing negative, } \\
\text { weak positive, and positive }\end{array}$ & 18 \\
\hline Dot blot (Immunoassay) & Colorimetry & Saliva & $>12 \mathrm{~h}$ & $\begin{array}{l}\text { Distinguishing negative, } \\
\text { weak positive, and positive }\end{array}$ & 19 \\
\hline $\begin{array}{c}\text { Electrochemical DNA } \\
\text { sensor linked with PCR }\end{array}$ & $\begin{array}{l}\text { Linear sweep } \\
\text { voltammetry }\end{array}$ & Saliva & $\begin{array}{l}>40 \text { min } \\
(40 \text { cycles })\end{array}$ & $10^{3}$ cells $/ \mathrm{mL}$ & 20 \\
\hline $\begin{array}{l}\text { Immunochromatographic } \\
\text { assay linked with real- } \\
\text { time PCR }\end{array}$ & Colorimetry & Saliva & $\sim 45 \mathrm{~min}$ & $5 \times 10^{5}$ cells $/ \mathrm{mL}$ & 21 \\
\hline $\begin{array}{l}\text { Electrochemical } \\
\text { detection }\end{array}$ & Chronocoulometry & $\begin{array}{l}\text { Artificial } \\
\text { saliva }\end{array}$ & $15 \mathrm{~min}$ & $5 \times 10^{5} \mathrm{CFU} / \mathrm{mL}$ & $\begin{array}{l}\text { This } \\
\text { Study }\end{array}$ \\
\hline
\end{tabular}




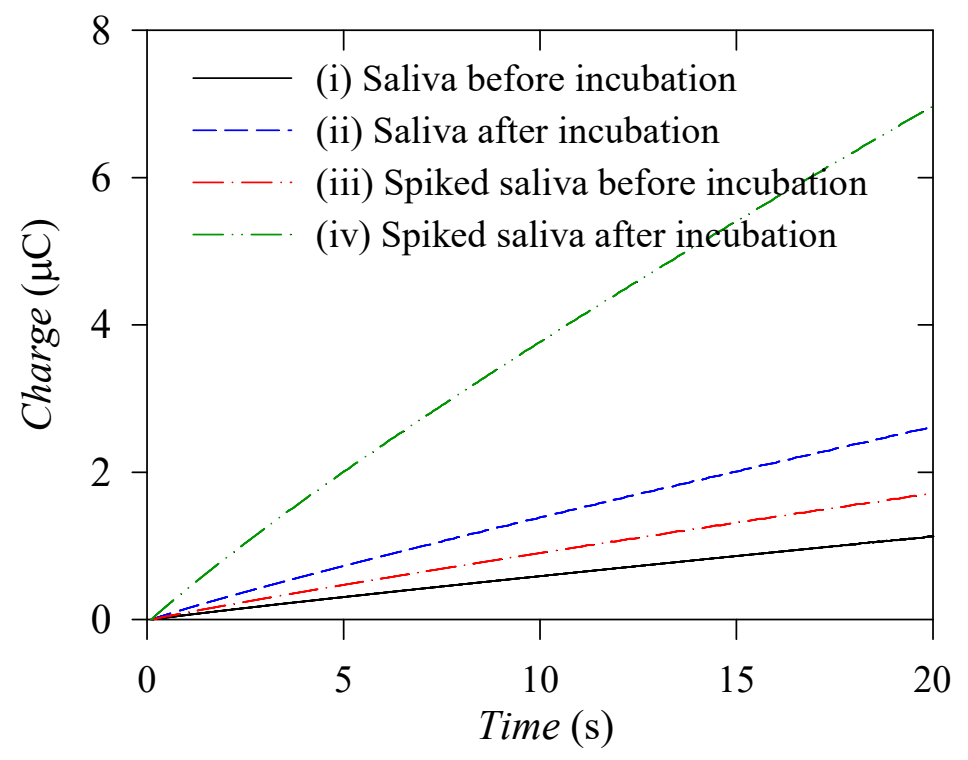

Figure S6. Chronocoulograms obtained (at $0.25 \mathrm{~V}$ ) using the schematic diagram of Figure 1 in human saliva at CNT- and BSA-modified ITO electrodes before (i, iii) and after (ii, iv) an incubation period of $15 \mathrm{~min}$ at $55^{\circ} \mathrm{C}$ in (i, ii) a mixed solution of $300 \mu \mathrm{L}$ of human saliva and $200 \mu \mathrm{L}$ of Tris buffer ( $\mathrm{pH} 7.5$ ) containing $0.1 \mathrm{mM}$ GPR-AP, $2.0 \mathrm{mM}$ TCEP, and $50 \mathrm{mM}$ Gly-Gly, and (iii, iv) a mixed solution of $300 \mu \mathrm{L}$ of human saliva spiked with $10^{7} \mathrm{CFU} / \mathrm{mL} P$. gingivalis and $200 \mu \mathrm{L}$ of Tris buffer $(\mathrm{pH} 7.5)$ containing 0.1 mM GPR-AP, $2.0 \mathrm{mM}$ TCEP, and $50 \mathrm{mM}$ Gly-Gly. 